\title{
The prioritisation of paediatrics and palliative care in cancer control plans in Africa
}

\author{
M S Weaver ${ }^{1}$, A J J Yao ${ }^{2}$, L A Renner ${ }^{3}$, M Harif ${ }^{4}$ and C G Lam ${ }^{\star}, 1,5$ \\ ${ }^{1}$ Department of Oncology, St Jude Children's Research Hospital, 262 Danny Thomas Place, MS 721, Memphis, TN 38105, USA; \\ ${ }^{2}$ Pediatric Oncology Service, Hôpital de Treichville, Abidjan, Côte d'Ivoire; ${ }^{3}$ Department of Child Health, University of Ghana \\ School of Medicine and Dentistry, Accra, Ghana; ${ }^{4}$ Cheikh Khalifa Hospital, Casablanca, Morocco and ${ }^{5}$ International Outreach \\ Program, St Jude Children's Research Hospital, Memphis, TN, USA
}

Background: Given the burden of childhood cancer and palliative care need in Africa, this paper investigated the paediatric and palliative care elements in cancer control plans.

Methods: We conducted a comparative content analysis of accessible national cancer control plans in Africa, using a health systems perspective attentive to context, development, scope, and monitoring/evaluation. Burden estimates were derived from World Bank, World Health Organisation, and Worldwide Palliative Care Alliance.

Results: Eighteen national plans and one Africa-wide plan (10 English, 9 French) were accessible, representing 9 low-, 4 lowermiddle-, and 5 upper-middle-income settings. Ten plans discussed cancer control in the context of noncommunicable diseases. Paediatric cancer was mentioned in 7 national plans, representing 5127 children, or 13\% of the estimated continental burden for children aged 0-14 years. Palliative care needs were recognised in 11 national plans, representing 157490 children, or 24\% of the estimated Africa-wide burden for children aged 0-14 years; four plans specified paediatric palliative needs. Palliative care was itemised in four budgets. Sample indicators and equity measures were identified, including those highlighting contextual needs for treatment access and completion.

Conclusions: Recognising explicit strategies and funding for paediatric and palliative services may guide prioritised cancer control efforts in resource-limited settings.

Of the 163284 children diagnosed with cancer per year in the world, an estimated 133301 live in 'less-developed' or low- and middle-income settings (Ferlay et al, 2013). Health ministries, nongovernmental organisations, hospitals, and academic and research institutes have championed the right to quality of life for cancer patients. Avoidance of programmatic redundancy and competition for limited resources requires strategic, implementable frameworks of cancer control inclusive of patients of all ages. Cancer control plans (CCPs) bring the potential to longitudinally coalesce policy-makers, health providers, patients, and advocates into a functional health delivery system for measurable cancer outcome improvement (Farmer et al, 2010). The World Health Organisation (WHO) describes national CCPs as 'public health programmes designed to reduce cancer incidence and mortality while improving the quality of life of cancer patients, through the systematic and equitable implementation of evidence-based strategies for prevention, early detection, diagnosis, treatment, and palliation, making the best use of available resources' (WHO, 2002). The Union for International Cancer Control (UICC) describes national CCPs as foundational for comprehensive cancer control, critical to the World Cancer Declaration (UICC, 2008).

The most recent GLOBOCAN data reveals that $\sim 847000$ new cancer cases were diagnosed in Africa in 2012 with an associated mortality rate of 591000 (Ferlay et al, 2013). Cancer registries are estimated to cover $<15 \%$ of the continent (Parkin, 2006), thus the

*Correspondence: Dr CG Lam; E-mail: Catherine.lam@stjude.org

The abstract of this article was presented as an oral presentation at the International Society of Paediatric Oncology (SIOP) Congress, 2014.

Received 30 December 2014; revised 15 March 2015; accepted 6 April 2015; published online 4 June 2015

(C) 2015 Cancer Research UK. All rights reserved 0007-0920/15 
exact incidence of cancer in Africa is grossly underestimated, particularly among children (Kruger et al, 2014). Unlike many adult cancers known to be associated with environmental exposures warranting screening and behavioural interventions, most paediatric cancers are not associated with modifiable risk factors. Paediatric cancers thus require a health system focus on early and accurate detection and treatment completion. Investment in these facets of cancer control has the potential to enhance national wellness and productivity, as the care of children represents the continent's future with youth aged between 0 and 14 years comprising of $43 \%$ of sub-Saharan Africa's population in 2013 (World Bank, 2014), an age demographic expected to grow (UNICEF, 2014). Alarmingly, cure rates for childhood cancer in some sub-Saharan African countries have been reported as $<10 \%$ (Ribeiro et al, 2008), and in some others, even treatment completion rates may be $<10 \%$ in the setting of high mortality and treatment abandonment rates (Slone et al, 2014). However, multicentre studies in Africa have shown that childhood cancer is curable in the context of provider training, adapted treatment regimens, and aggressive supportive care. For example, the Wilms tumor treatment protocol resulted in 93\% treatment completion and $46 \%$ overall survival in Malawi (Israels et al, 2012), an approach now initiated as a multisite prospective clinical trial in eight African centres. The French-African Paediatric Oncology Group (GFAOP), with personnel training and joint treatment protocols, revealed the survival rate of Burkitt lymphoma protocols adapted for Africa at a 3-year overall survival of $61 \%$ (Harif et al, 2008). The priorities and strategies delineated in national CCPs represent the opportunity for establishing a national commitment to patient outcomes by enhancing cure through frameworks of sustained treatment approaches, for even the most vulnerable of community members (Sullivan et al, 2013).

This research sought to first identify cancer control plans in Africa and to analyse the national control plan content for inclusiveness of paediatric populations. Given the current reality of late diagnoses and limited access to advanced curative therapies for many children in Africa, palliative care constitutes a critical component (Amery et al, 2009) that we sought to analyse. According to the Worldwide Palliative Care Alliance (WPCA), $49 \%$ of children in need of palliative care globally are found within the African Region (WPCA, 2014). A report commissioned by the United Nations Children Fund recently reported that the number of youth reaching palliative care services in South Africa and Zimbabwe in 2012 represented only $5 \%$ of the children with palliative care needs, while the number in Kenya was $1 \%$ (UNICEF and ICPCN, 2013), thus drawing attention to the urgent need for palliative care scale-up for children on the continent. Furthermore, recognising the variability in palliative care provision in Africa with many countries described as having limited capacity building or isolated provision only (Knapp et al, 2011; Lynch et al, 2013; WPCA, 2014), depiction of palliative care needs in CCPs could be a critical step in promoting integrated and implemented services. Aware of the role that socioeconomic contexts such as rural vs urban contexts, private $v s$ public access, health literacy, and poverty have in health outcomes (Sullivan, 2012), the study team was attentive to social determinants, stakeholder inclusion, and equity prioritisation, as components of cancer control contextual and developmental considerations (WHO, 2009). Finally, monitoring and evaluation components of CCPs were examined, including recognition of data registries, equity measures, and treatment completion.

This study describes the current state of cancer control models in Africa from a paediatric, palliative, and quality inclusive health systems perspective. The study team intended to provide an overview of publicly available plans as a platform to capture existing context-specific elements, to celebrate examples of inclusion, and to identify opportunities for synergy.

\section{MATERIALS AND METHODS}

Search strategy and inclusion criteria. We identified African countries reporting to WHO as having a national cancer plan (WHO, 2010). We included in our study all publicly available CCPs. We identified and sourced these CCPs through database searches including the UICC International Cancer Control Partnership (ICCIP) portal (UICC, 2014), communication with Ministry of Health representatives, and through Google searches with combinations of the terms 'oncology,' 'cancer,' 'malignancy,' 'plan,' and 'strategy' with and without individual country names. The last search was completed on 12 October 2014. We analyzed the contents of publicly available CCPs, but did not include plans that were either publicly unavailable or in process. We excluded from our analysis national health policies that only focussed on subcomponent analysis, such as cervical cancer screening or evaluation-only documents.

Data extraction and analysis. Structured analysis was guided by existing frameworks for CCP analyses, including the WHO's national cancer control programme guidelines and assessment tool (WHO, 2002), Centres for Disease Control and Prevention's Guidance for Cancer Control Planning (Given et al, 2010), the American Cancer Society's National Action Plan for Childhood Cancer (American Cancer Society, 2000), the UICC Toolkit for Cancer Control Planning (UICC, 2012), the European Cancer Control Plan Evaluation Analysis (Atun et al, 2009), and global insights from the Third International Cancer Control Congress (Harford et al, 2009), adapted to the local context. Resources providing additional insight into locally relevant extraction and interpretation priorities included the Lancet Oncology Cancer Control in Africa series (Harding et al, 2013; Harif et al, 2013; Stefan et al, 2013; Vento, 2013) and health systems assessments, such as the African Child Policy Forum's Report on Child Wellbeing and Child Friendliness Index (Bequele, 2010). Data extraction was based on elements of cancer control as outlined by WHO (2006) with emphasis on context, development, scope, and monitoring and evaluation (Figure 1). The data extraction template was piloted on two plans and revised to reach team consensus (Supplementary Appendix 1). Data extraction occurred by two independent reviewers with content independently verified by study team members. Discrepancies were resolved by discussion and consensus. In recognition that cancer care may be provided for children within a continuum of services spanning age groups, cancer control aspects nonspecific for age were also extracted. Country income classifications were based on the World Bank income classification by gross national income per capita as of July 2013 listings (World Bank, 2014). Population and continental

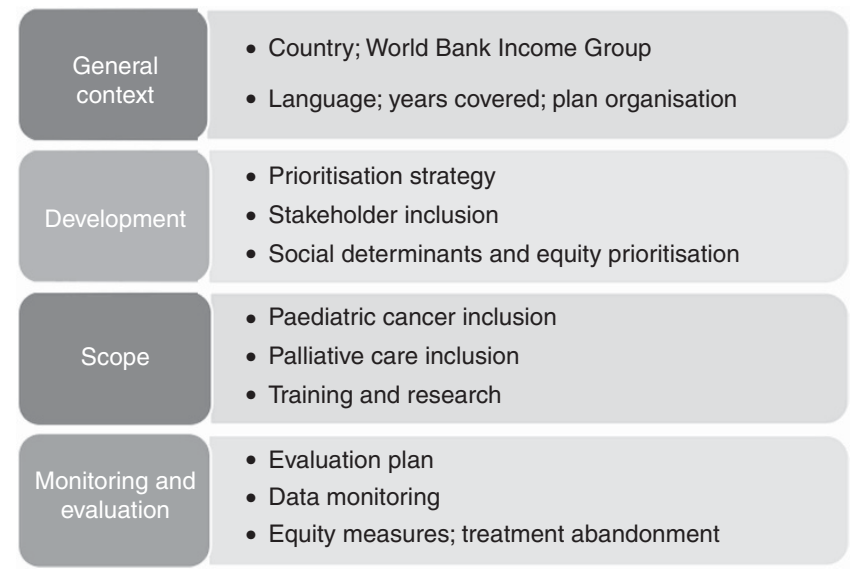

Figure 1. Data extraction emphasis. 
burden estimates for analyses were collected from current World Bank (World Bank, 2014), GLOBOCAN (Ferlay et al, 2013), and WPCA/WHO data (WPCA, 2014).

Role of the funding source. No sources of funding affected this study. The first and corresponding authors had full access to all data and final responsibility for submission.

\section{RESULTS}

Seventeen countries reported to the WHO as having a plan in 2010 (WHO, 2010); 22 plans were identified through the ICCP portal (UICC, 2014) and one identified through contact with a Health Minister, resulting in 19 non-duplicate evaluable plans (Figure 2). Of these, one was the African Organisation for Research and Training (AORTIC) Cancer Plan for the African Continent (African Organisation for Research and Training in Cancer, (AORTIC), 2013-2017) and 18 were national: Algeria (Algérie Département de la Santé, 2010-2019), Benin (République de Bénin Ministère de la Santé, 2014-2018), Botswana (Ministry of Health Government of Botswana, 2010), Burkina Faso (Burkina Faso Ministère de la Santé, 2013), Côte d'Ivoire (Ministère de la Santé et de la Lutte contre le SIDA République de Côte d'Ivoire, 2011-2014), Gabon (République Gabonaise Ministère de la Santé des Affaires Sociales de la Solidarité et de la Famille, 2010), Ghana (Ghana Ministry of Health, 2011), Kenya (Republic of Kenya Ministry of Public Health and Sanitation and Ministry of Medical Services, 2011-2016), Madagascar (Ministère de la Santé Publique République du Madagascar, 2010), Malawi (Malawi Ministry of Health, 2011-2016), Mali (Ministère de la Santé République du Mali, 2013), Mauritius (Republic of Mauritius Ministry of Health and Quality of Life, 2010-2014), Morocco (Morocco Ministère de la Santé and Association Lalla Salma de Lutte Contre le Cancer, 2010-2019), Senegal (République du Sénégal Ministère de la Santé et de la Prévention, 2009), South Africa (South Africa Ministry of Health, 2013-2017), Sudan (Republic of the Sudan Federal Ministry of Health, 2003-2027), Togo (République Togolaise Ministère de la Santé, 2012), and Zimbabwe (Zimbabwe Ministry of Health and Child Welfare, 2013-2017).

Context. Ten plans were reviewed in English (Republic of the Sudan Federal Ministry of Health, 2003-2027; Ministry of Health Government of Botswana, 2010; Republic of Mauritius Ministry of Health and Quality of Life, 2010-2014; Morocco Ministère de la Santé and Association Lalla Salma de Lutte Contre le Cancer, 2010-2019; Ghana Ministry of Health, 2011; Malawi Ministry of Health, 2011-2016; Republic of Kenya Ministry of Public Health and Sanitation and Ministry of Medical Services, 2011-2016;
African Organisation for Research and Training in Cancer (AORTIC), 2013-2017; South Africa Ministry of Health, 2013-2017; Zimbabwe Ministry of Health and Child Welfare, 2013-2017) and nine were reviewed in French (République du Sénégal Ministère de la Santé et de la Prévention, 2009; Ministère de la Santé Publique République du Madagascar, 2010; République Gabonaise Ministère de la Santé des Affaires Sociales de la Solidarité et de la Famille, 2010; Algérie Département de la Santé, 2010-2019; Ministère de la Santé et de la Lutte contre le SIDA République de Côte d'Ivoire, 2011-2014; République Togolaise Ministère de la Santé, 2012; Burkina Faso Ministère de la Santé, 2013; Ministère de la Santé République du Mali, 2013; République de Bénin Ministère de la Santé, 2014-2018). Nine plans represented countries with low-income economies (République du Sénégal Ministère de la Santé et de la Prévention, 2009; Ministère de la Santé Publique République du Madagascar, 2010; Malawi Ministry of Health, 2011-2016; Republic of Kenya Ministry of Public Health and Sanitation and Ministry of Medical Services, 2011-2016; République Togolaise Ministère de la Santé, 2012; Burkina Faso Ministère de la Santé, 2013; Ministère de la Santé République du Mali, 2013; Zimbabwe Ministry of Health and Child Welfare, 2013-2017; République de Bénin Ministère de la Santé, 2014-2018), four represented lower-middleincome economies (Republic of the Sudan Federal Ministry of Health, 2003-2027; Morocco Ministère de la Santé and Association Lalla Salma de Lutte Contre le Cancer, 2010-2019; Ghana Ministry of Health, 2011; Ministère de la Santé et de la Lutte contre le SIDA République de Côte d'Ivoire, 2011-2014), and five represented upper-middle-income economies (Ministry of Health Government of Botswana, 2010; République Gabonaise Ministère de la Santé des Affaires Sociales de la Solidarité et de la Famille, 2010; Republic of Mauritius Ministry of Health and Quality of Life, 2010-2014; Algérie Département de la Santé, 2010-2019; South Africa Ministry of Health, 2013-2017), per World Bank (World Bank, 2014) (Figure 3). Plans spanned from 1 (Ministère de la Santé Publique République du Madagascar, 2010) to 25 years (Republic of the Sudan Federal Ministry of Health, 2003-2027), median 5 years with timeframe 2003-2027. Ten were part of larger noncommunicable disease (NCD) national plans (Republic of the Sudan Federal Ministry of Health, 2003-2027; République du Sénégal Ministère de la Santé et de la Prévention, 2009; Ministry of Health Government of Botswana, 2010; République Gabonaise Ministère de la Santé des Affaires Sociales de la Solidarité et de la Famille, 2010; Ministère de la Santé et de la Lutte contre le SIDA République de Côte d'Ivoire, 2011-2014; Malawi Ministry of Health, 2011-2016; République Togolaise Ministère de la Santé, 2012; Ministère de la Santé République du Mali, 2013; South Africa Ministry of Health, 2013-2017; République de Bénin Ministère de

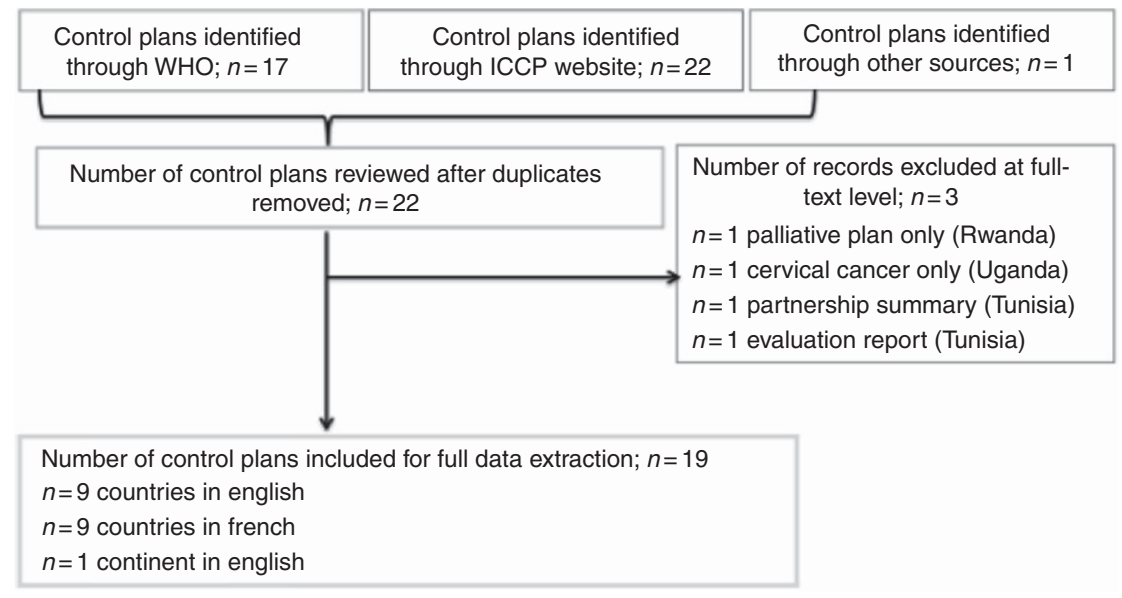

Figure 2. PRISMA flow of plan inclusion. ICCP = International Cancer Control Partnership. 


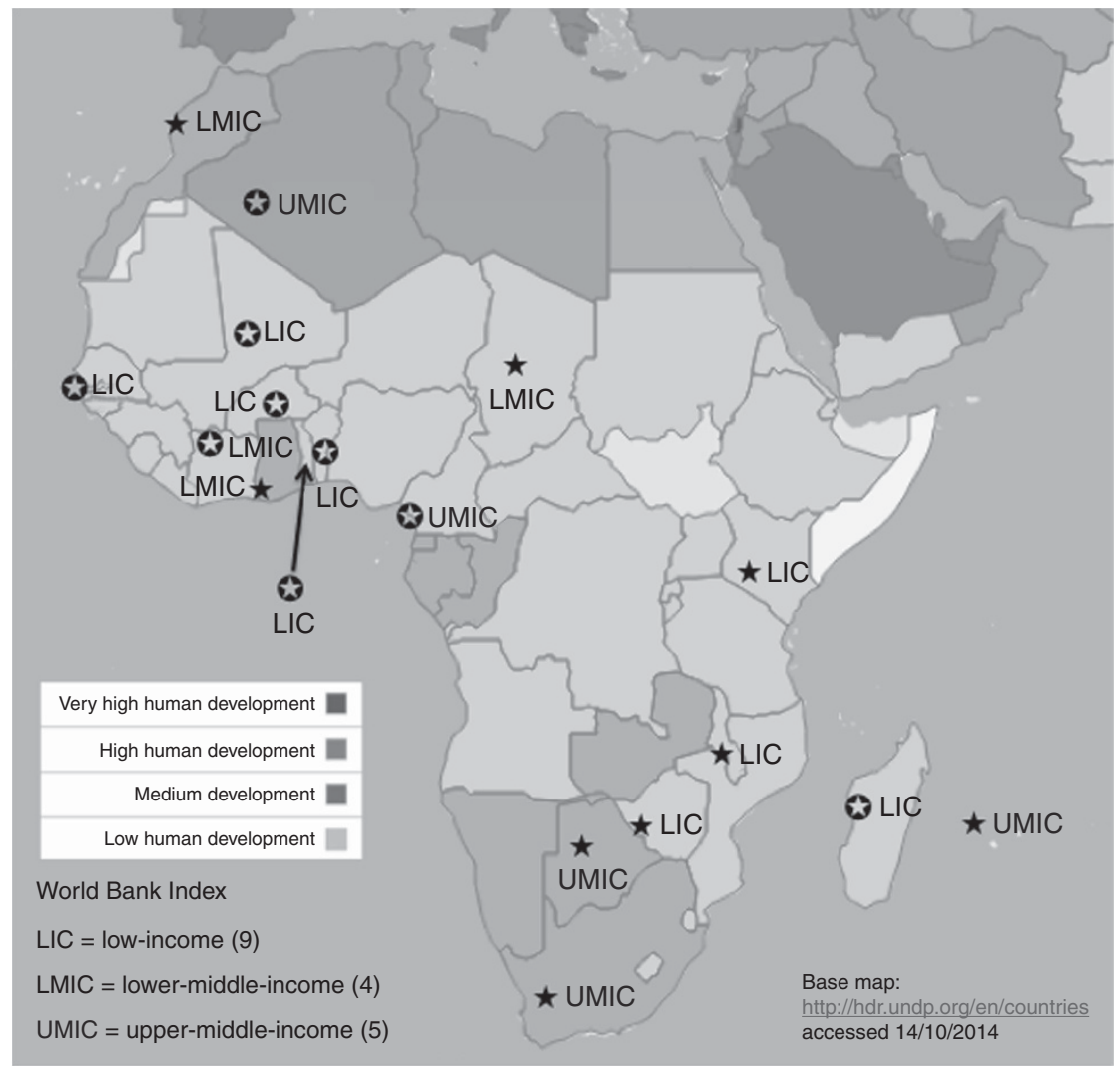

Figure 3. Countries with plans reviewed in context of Human Development Index-utilised base map unaltered as available from Human Development Reports, United Nations Development Programme, available from http://hdr.undp.org/en/countries (last accessed 14 October 2014); for illustrative purposes only. in French: Algeria, Benin, Burkina Faso, Côte d' Ivoire, Gabon, Madagascar, Mali, Senegal, and Togo. $\star$ in English: Botswana, black Ghana, Kenya, Malawi, Mauritius, Morocco, South Africa, Sudan, and Zimbabwe.

la Santé, 2014-2018) and nine were cancer-specific plans (Ministère de la Santé Publique République du Madagascar, 2010; Republic of Mauritius Ministry of Health and Quality of Life, 2010-2014; Algérie Département de la Santé, 2010-2019; Morocco Ministère de la Santé and Association Lalla Salma de Lutte Contre le Cancer, 2010-2019; Ghana Ministry of Health, 2011; Republic of Kenya Ministry of Public Health and Sanitation and Ministry of Medical Services, 2011-2016; Burkina Faso Ministère de la Santé, 2013; African Organisation for Research and Training in Cancer (AORTIC), 2013-2017; Zimbabwe Ministry of Health and Child Welfare, 2013-2017). Of the cancer-specific plans, all but one country (Republic of Kenya Ministry of Public Health and Sanitation and Ministry of Medical Services, 2011-2016) had a prior NCD strategic document in place.

\section{Development}

Prioritisation strategy. Every plan prioritised interventions within the context of local needs. Cancer control plans listed the following as influences in prioritising interventions: cost effectiveness (République du Sénégal Ministère de la Santé et de la Prévention, 2009; Ministère de la Santé République du Mali, 2013; South Africa Ministry of Health, 2013-2017), perceived efficiency (Ministry of Health Government of Botswana, 2010; Republic of Kenya Ministry of Public Health and Sanitation and Ministry of Medical Services, 2011-2016), current burden of disease (Ministère de la Santé Publique République du Madagascar, 2010; Malawi Ministry of Health, 2011-2016; Burkina Faso Ministère de la Santé, 2013; Ministère de la Santé République du Mali, 2013), evidence-based for prevention or cure success (Malawi Ministry of Health, 2011-2016; Republic of Kenya Ministry of Public Health and Sanitation and Ministry of Medical Services,
2011-2016; African Organisation for Research and Training in Cancer (AORTIC), 2013-2017; South Africa Ministry of Health, 2013-2017), anticipated community or population-level health impact (République Gabonaise Ministère de la Santé des Affaires Sociales de la Solidarité et de la Famille, 2010; Republic of Mauritius Ministry of Health and Quality of Life, 2010-2014; Ghana Ministry of Health, 2011; Republic of Kenya Ministry of Public Health and Sanitation and Ministry of Medical Services, 2011-2016; Zimbabwe Ministry of Health and Child Welfare, 2013-2017), and existing and potential resources (Republic of the Sudan Federal Ministry of Health, 2003-2027; Morocco Ministère de la Santé and Association Lalla Salma de Lutte Contre le Cancer, 2010-2019; Ghana Ministry of Health, 2011).

Stakeholder inclusion. Survivors, patients, and/or parents were specifically mentioned as contributors in plan design or development in five plans (Ministry of Health Government of Botswana, 2010; Ghana Ministry of Health, 2011; Ministère de la Santé et de la Lutte contre le SIDA République de Côte d'Ivoire, 2011-2014; South Africa Ministry of Health, 2013-2017; Zimbabwe Ministry of Health and Child Welfare, 2013-2017), with mention of patient and survivor engagement in five additional plans (Ministère de la Santé Publique République du Madagascar, 2010; République Gabonaise Ministère de la Santé des Affaires Sociales de la Solidarité et de la Famille, 2010; Algérie Département de la Santé, 2010-2019; Republic of Kenya Ministry of Public Health and Sanitation and Ministry of Medical Services, 2011-2016; République Togolaise Ministère de la Santé, 2012). Three plans specifically targeted women and youth in health development (Ministère de la Santé Publique République du Madagascar, 2010; République Gabonaise Ministère de la Santé des Affaires Sociales de la Solidarité et de la Famille, 2010; Ministère de la Santé 
République du Mali, 2013). Four plans recognised cancer survivors as partners, committing to improving survivor quality of life (Republic of Kenya Ministry of Public Health and Sanitation and Ministry of Medical Services, 2011-2016; African Organisation for Research and Training in Cancer (AORTIC), 2013-2017; South Africa Ministry of Health, 2013-2017; Zimbabwe Ministry of Health and Child Welfare, 2013-2017). The community was recognised not simply as a beneficiary but as an actor (République Togolaise Ministère de la Santé, 2012), noting that 'it takes a village' for improved cancer outcomes (African Organisation for Research and Training in Cancer (AORTIC), 2013-2017). Cancer control plan frameworks emphasised interdisciplinary team partnerships with nursing, nutrition, social work, psychology, hospital chaplaincy, and local religious groups along with core subspecialties such as surgery, radiation oncology, and infectious diseases. Policy-makers and governing officials, NGOs, civil societies, regional, and international partnership were represented as essential collaborators for plan implementation. Media groups were recognised as essential publicity partners (Republic of the Sudan Federal Ministry of Health, 2003-2027; République du Sénégal Ministère de la Santé et de la Prévention, 2009; Ministry of Health Government of Botswana, 2010; Republic of Mauritius Ministry of Health and Quality of Life, 2010-2014; Morocco Ministère de la Santé and Association Lalla Salma de Lutte Contre le Cancer, 2010-2019; Ghana Ministry of Health, 2011; Republic of Kenya Ministry of Public Health and Sanitation and Ministry of Medical Services, 2011-2016; République Togolaise Ministère de la Santé, 2012; African Organisation for Research and Training in Cancer (AORTIC), 2013-2017; South Africa Ministry of Health, 2013-2017; Zimbabwe Ministry of Health and Child Welfare, 2013-2017).

Social determinants. Cancer control plans recognised the critical role of addressing 'pathways of the relationships between population health and the social, economic, and political environments in which people live' as 'the causes of the causes of ill health' (South Africa Ministry of Health, 2013-2017). Lack of adequate attention to social determinants of health was viewed as a weakness of prior health frameworks (Malawi Ministry of Health, 2011-2016). Social anthropology (Morocco Ministère de la Santé and Association Lalla Salma de Lutte Contre le Cancer, 2010-2019) and sociological approaches (Ministère de la Santé et de la Lutte contre le SIDA République de Côte d'Ivoire, 2011-2014) were valued for strengthening health delivery efforts. Prevailing cultural beliefs and practices were acknowledged in control plans not only in general attitudes towards cancer and health but also as practical influences on the time to diagnosis and treatment (Malawi Ministry of Health, 2011-2016) and even as influential on consent for blood donations (République Gabonaise Ministère de la Santé des Affaires Sociales de la Solidarité et de la Famille, 2010). While traditional medicine was recognised in some cases as potentially adding to the complexity of cancer control, multiple plans described the local importance of traditional medicine (République du Sénégal Ministère de la Santé et de la Prévention, 2009; Ministère de la Santé Publique République du Madagascar, 2010; Ministry of Health Government of Botswana, 2010; République Gabonaise Ministère de la Santé des Affaires Sociales de la Solidarité et de la Famille, 2010; Morocco Ministère de la Santé and Association Lalla Salma de Lutte Contre le Cancer, 2010-2019; Ghana Ministry of Health, 2011; Ministère de la Santé et de la Lutte contre le SIDA République de Côte d'Ivoire, 20112014; Malawi Ministry of Health, 2011-2016; République Togolaise Ministère de la Santé, 2012; Ministère de la Santé République du Mali, 2013; South Africa Ministry of Health, 2013-2017; Zimbabwe Ministry of Health and Child Welfare, 2013-2017). Several specified intent to prioritise integration and engagement of traditional healers in promoting cancer care outcomes, including
Botswana, Gabon, Mali, and Senegal. Traditional healers were discussed in the context of 'recognising the cultural heritage and traditional knowledge of indigenous peoples and respecting, preserving and promoting, as appropriate, their traditional medicine, including conservation of their vital medicinal plants, animals, and minerals' (South Africa Ministry of Health, 2013-2017) in the South African plan with reference to implemented policy protections for traditional medicine in Burkina Faso (Burkina Faso Ministère de la Santé, 2013).

Health literacy. Limited educational literacy of the population-atlarge was recognised as a risk to health outcomes in the continental plan (African Organisation for Research and Training in Cancer (AORTIC), 2013-2017) and nine national plans (Republic of the Sudan Federal Ministry of Health, 2003-2027; République du Sénégal Ministère de la Santé et de la Prévention, 2009; Ministère de la Santé Publique République du Madagascar, 2010; République Gabonaise Ministère de la Santé des Affaires Sociales de la Solidarité et de la Famille, 2010; Ministère de la Santé et de la Lutte contre le SIDA République de Côte d'Ivoire, 2011-2014; Malawi Ministry of Health, 2011-2016; République Togolaise Ministère de la Santé, 2012; Burkina Faso Ministère de la Santé, 2013; République de Bénin Ministère de la Santé, 2014-2018) with specific mention of gender disparity in population literacy levels in three plans (République du Sénégal Ministère de la Santé et de la Prévention, 2009; République Gabonaise Ministère de la Santé des Affaires Sociales de la Solidarité et de la Famille, 2010; République Togolaise Ministère de la Santé, 2012).

Specifically, inadequate health literacy was recognised as a targetable barrier to healthy living (Ministry of Health Government of Botswana, 2010; South Africa Ministry of Health, 2013-2017) as was limited cancer education for the public (Morocco Ministère de la Santé and Association Lalla Salma de Lutte Contre le Cancer, 2010-2019; Ghana Ministry of Health, 2011; Burkina Faso Ministère de la Santé, 2013; Zimbabwe Ministry of Health and Child Welfare, 2013-2017).

Equity prioritisation. Attentiveness to equity was stated in 18 of 19 plans (Republic of the Sudan Federal Ministry of Health, 2003-2027; République du Sénégal Ministère de la Santé et de la Prévention, 2009; Ministry of Health Government of Botswana, 2010; Ministère de la Santé Publique République du Madagascar, 2010; République Gabonaise Ministère de la Santé des Affaires Sociales de la Solidarité et de la Famille, 2010; Algérie Département de la Santé, 2010-2019; Morocco Ministère de la Santé and Association Lalla Salma de Lutte Contre le Cancer, 2010-2019; Ghana Ministry of Health, 2011; Ministère de la Santé et de la Lutte contre le SIDA République de Côte d'Ivoire, 2011-2014; Malawi Ministry of Health, 2011-2016; Republic of Kenya Ministry of Public Health and Sanitation and Ministry of Medical Services, 2011-2016; République Togolaise Ministère de la Santé, 2012; Burkina Faso Ministère de la Santé, 2013; African Organisation for Research and Training in Cancer (AORTIC), 2013-2017; République de Bénin Ministère de la Santé, 2014-2018; Ministère de la Santé République du Mali, 2013; South Africa Ministry of Health, 2013-2017; Zimbabwe Ministry of Health and Child Welfare, 2013-2017). A number of plans promoted equity as a guiding principle, for example, in the Zimbabwean plan, which defined equity as 'fair and non-discriminatory access to cancer services' (Zimbabwe Ministry of Health and Child Welfare, 20132017). Reference to access to services for the poor was specified in 15 plans (Republic of the Sudan Federal Ministry of Health, 2003-2027; République du Sénégal Ministère de la Santé et de la Prévention, 2009; Ministry of Health Government of Botswana, 2010; Ministère de la Santé Publique République du Madagascar, 2010; République Gabonaise Ministère de la Santé des Affaires Sociales de la Solidarité et de la Famille, 2010; Morocco Ministère 
de la Santé and Association Lalla Salma de Lutte Contre le Cancer, 2010-2019; Ministère de la Santé et de la Lutte contre le SIDA République de Côte d'Ivoire, 2011-2014; Malawi Ministry of Health, 2011-2016; Republic of Kenya Ministry of Public Health and Sanitation and Ministry of Medical Services, 2011-2016; République Togolaise Ministère de la Santé, 2012; Ministère de la Santé République du Mali, 2013African Organisation for Research and Training in Cancer (AORTIC), 2013-2017; South Africa Ministry of Health, 2013-2017; République de Bénin Ministère de la Santé, 2014-2018; ), with recognition of the poverty cycle in cancer (African Organisation for Research and Training in Cancer (AORTIC), 2013-2017), exacerbated by the burden of treatment costs (Morocco Ministère de la Santé and Association Lalla Salma de Lutte Contre le Cancer, 2010-2019; African Organisation for Research and Training in Cancer (AORTIC), 2013-2017), as well as being associated with adverse cancer outcome disparities (Republic of Kenya Ministry of Public Health and Sanitation and Ministry of Medical Services, 2011-2016; African Organisation for Research and Training in Cancer (AORTIC), 2013-2017). Attention to gender disparities and gender sensitivity were specified in several plans (Republic of the Sudan Federal Ministry of Health, 2003-2027; Ministry of Health Government of Botswana, 2010; Ministère de la Santé Publique République du Madagascar, 2010; République Gabonaise Ministère de la Santé des Affaires Sociales de la Solidarité et de la Famille, 2010; Republic of Mauritius Ministry of Health and Quality of Life, 2010-2014; Ghana Ministry of Health, 2011; Ministère de la Santé et de la Lutte contre le SIDA République de Côte d'Ivoire, 2011-2014; Malawi Ministry of Health, 2011-2016; Republic of Kenya Ministry of Public Health and Sanitation and Ministry of Medical Services, 2011-2016; Burkina Faso Ministère de la Santé, 2013; Ministère de la Santé République du Mali, 2013); for instance, Malawi noted gender inequities potentially affecting malnutrition in children (Malawi Ministry of Health, 2011-2016), whereas Botswana noted the guiding value of equal engagement of both genders in health decision-making (Ministry of Health Government of Botswana, 2010). Urbanisation and population crowding was recognised as a health risk (Republic of the Sudan Federal Ministry of Health, 2003-2027; Ghana Ministry of Health, 2011; Malawi Ministry of Health, 2011-2016; Republic of Kenya Ministry of Public Health and Sanitation and Ministry of Medical Services, 2011-2016; South Africa Ministry of Health, 2013-2017). The unique educational and geographic barriers to diagnosis and cure for patients in rural settings were acknowledged (Republic of the Sudan Federal Ministry of Health, 2003-2027; République du Sénégal Ministère de la Santé et de la Prévention, 2009; Ministère de la Santé Publique République du Madagascar, 2010; Ministry of Health
Government of Botswana, 2010; Morocco Ministère de la Santé and Association Lalla Salma de Lutte Contre le Cancer, 2010-2019; République Gabonaise Ministère de la Santé des Affaires Sociales de la Solidarité et de la Famille, 2010; Malawi Ministry of Health, 2011-2016; Ministère de la Santé et de la Lutte contre le SIDA République de Côte d'Ivoire, 2011-2014; République Togolaise Ministère de la Santé, 2012; Burkina Faso Ministère de la Santé, 2013; South Africa Ministry of Health, 2013-2017; Zimbabwe Ministry of Health and Child Welfare, 2013-2017), with recognition of cancer fatalism in certain rural regions (Morocco Ministère de la Santé and Association Lalla Salma de Lutte Contre le Cancer, 2010-2019). All plans distinguished private and public health sectors, with particular service provision needs or disease control roles.

\section{Scope}

Paediatric cancer. Paediatric cancer was recognised in seven of 18 national control plans (Ministère de la Santé Publique République du Madagascar, 2010; Republic of Mauritius Ministry of Health and Quality of Life, 2010-2014; Morocco Ministère de la Santé and Association Lalla Salma de Lutte Contre le Cancer, 2010-2019; Ghana Ministry of Health, 2011; Burkina Faso Ministère de la Santé, 2013; Zimbabwe Ministry of Health and Child Welfare, 2013-2017), representing 5127 children with cancer, or $13 \%$ of the total estimated burden for children in Africa between the ages of 0 and 14 years using current population (World Bank, 2014) and estimated cancer incidence data (Parkin et al, 1988; Howard et al, 2008; Ferlay et al, 2013; Magrath et al, 2013). These seven national CCPs (Ministère de la Santé Publique République du Madagascar, 2010; Republic of Mauritius Ministry of Health and Quality of Life, 2010-2014; Algérie Département de la Santé, 2010-2019; Morocco Ministère de la Santé and Association Lalla Salma de Lutte Contre le Cancer, 2010-2019; Ghana Ministry of Health, 2011; Burkina Faso Ministère de la Santé, 2013; Zimbabwe Ministry of Health and Child Welfare, 2013-2017) and one continental plan (African Organisation for Research and Training in Cancer (AORTIC), 2013-2017) specified elements of paediatric-specific cancer detection, diagnosis, and/or treatment as a priority. Early detection of paediatric cancer was specifically promoted in three plans (Morocco Ministère de la Santé and Association Lalla Salma de Lutte Contre le Cancer, 2010-2019; Ghana Ministry of Health, 2011; Zimbabwe Ministry of Health and Child Welfare, 2013-2017), with Zimbabwe and Ghana urging inclusion of simple clinical assessments (as for retinoblastoma or for abdominal masses) in routine primary health services. Scale-up of human resources and paediatric cancer facilities were each mentioned in six plans, whereas

Table 1. Inclusion of paediatric cancer in control plans

\begin{tabular}{|c|c|c|c|c|c|c|c|}
\hline \multirow[b]{2}{*}{ Country $^{a}$} & \multicolumn{7}{|c|}{ Inclusion of paediatric cancer in plan } \\
\hline & General & Facilities & Technology & Drugs & $\begin{array}{l}\text { Human } \\
\text { resources }\end{array}$ & Budget & Evaluation \\
\hline \multicolumn{8}{|c|}{ Low-income economies } \\
\hline $\begin{array}{l}\text { Madagascar } \\
\text { Burkina Faso } \\
\text { Zimbabwe }\end{array}$ & 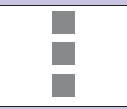 & 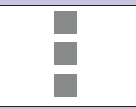 & $\square$ & 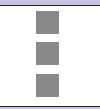 & 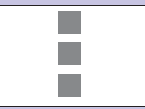 & & 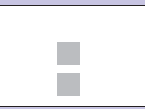 \\
\hline \multicolumn{8}{|c|}{ Lower-middle-income economies } \\
\hline $\begin{array}{l}\text { Ghana } \\
\text { Morocco }\end{array}$ & $\square$ & 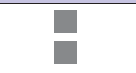 & $\square$ & $\square$ & $\square$ & & 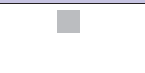 \\
\hline \multicolumn{8}{|c|}{ Upper-middle-income economies } \\
\hline $\begin{array}{l}\text { Algeria } \\
\text { Mauritius }\end{array}$ & & $\square$ & $\square$ & $\square$ & $\square$ & $\square$ & $\square$ \\
\hline Continental & $\square$ & & & & 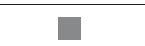 & & 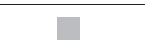 \\
\hline
\end{tabular}


chemotherapeutics or supportive care drugs specifically for treatment of childhood cancers were noted in five plans (Table 1). Paediatric cancer treatment regimens were noted in three plans (Ghana Ministry of Health, 2011; African Organisation for Research and Training in Cancer (AORTIC), 2013-2017; Zimbabwe Ministry of Health and Child Welfare, 2013-2017). Depiction of paediatricspecific technology include special radiation oncology linear accelerators for children in Zimbabwe (Zimbabwe Ministry of Health and Child Welfare, 2013-2017), surgical and anesthesia equipment specific for children with cancer in Ghana (Ghana Ministry of Health, 2011), and central lines sized specifically for paediatric size patients in Mauritius (Republic of Mauritius Ministry of Health and Quality of Life, 2010-2014). Paediatric cancer was itemised in the budget in one national control plan (Republic of Mauritius Ministry of Health and Quality of Life, 2010-2014).

Childhood cancer prevention and community education. Fifteen plans proposed general cancer prevention through public health measures starting in childhood. Childhood vaccines were mentioned most often, as hepatitis immunisations considered within the context of hepatocellular cancer control (Sitas et al, 2008; Momin and Richardson, 2012) in addition to infectious control. Plans targeted prevention of cervical cancer through HPV vaccines (Ministère de la Santé Publique République du Madagascar, 2010; Algérie Département de la Santé, 2010-2019; Morocco Ministère de la Santé and Association Lalla Salma de Lutte Contre le Cancer, 2010-2019; Malawi Ministry of Health, 2011-2016; République Togolaise Ministère de la Santé, 2012; Burkina Faso Ministère de la Santé, 2013; Zimbabwe Ministry of Health and Child Welfare, 2013-2017; République de Bénin Ministère de la Santé, 2014-2018) with some specifying targeted educational messaging for adolescents along with vaccine provision (Ministère de la Santé Publique République du Madagascar, 2010; Ghana Ministry of Health, 2011; South Africa Ministry of Health, 2013-2017). School-based health promotion was noted in several plans (Republic of the Sudan Federal Ministry of Health, 2003-2027; Ministry of Health Government of Botswana, 2010; Republic of Mauritius Ministry of Health and Quality of Life, 2010-2014; Morocco Ministère de la Santé and Association Lalla Salma de Lutte Contre le Cancer, 2010-2019; Ghana Ministry of Health, 2011; Ministère de la Santé et de la Lutte contre le SIDA République de Côte d'Ivoire, 2011-2014; Republic of Kenya Ministry of Public Health and
Sanitation and Ministry of Medical Services, 2011-2016; République Togolaise Ministère de la Santé, 2012; South Africa Ministry of Health, 2013-2017; Zimbabwe Ministry of Health and Child Welfare, 2013-2017; République de Bénin Ministère de la Santé, 2014-2018). Examples of other health-relevant preventions targeted to children included limiting sun exposure for children (Zimbabwe Ministry of Health and Child Welfare, 2013-2017), malaria prevention (Ghana Ministry of Health, 2011), improved overall nutrition (Morocco Ministère de la Santé and Association Lalla Salma de Lutte Contre le Cancer, 2010-2019), increased physical activity (République de Bénin Ministère de la Santé, 2014-2018), and HIV/AIDS prevention (Ministry of Health Government of Botswana, 2010; South Africa Ministry of Health, 2013-2017). Several plans noted trends in alcohol and tobacco use among adolescents (African Organisation for Research and Training in Cancer (AORTIC), 2013-2017; South Africa Ministry of Health, 2013-2017); sample plans targeted adolescent smoking (Ministry of Health Government of Botswana, 2010; République Togolaise Ministère de la Santé, 2012) or legislation against the sale of tobacco or alcohol to minors (Ghana Ministry of Health, 2011).

Palliative care. Palliative care provision (National Consensus Project for Quality Palliative Care, 2013; WPCA, 2014) was recognised in 11 of 18 national CCPs (Ministère de la Santé Publique République du Madagascar, 2010; Republic of Mauritius Ministry of Health and Quality of Life, 2010-2014; Algérie Département de la Santé, 2010-2019; Morocco Ministère de la Santé and Association Lalla Salma de Lutte Contre le Cancer, 2010-2019; Ghana Ministry of Health, 2011; Ministère de la Santé et de la Lutte contre le SIDA République de Côte d'Ivoire, 2011-2014; Malawi Ministry of Health, 2011-2016; Republic of Kenya Ministry of Public Health and Sanitation and Ministry of Medical Services, 2011-2016; Burkina Faso Ministère de la Santé, 2013; South Africa Ministry of Health, 2013-2017; Zimbabwe Ministry of Health and Child Welfare, 2013-2017), representing 157490 children, or $24 \%$ of total expected continental burden for children aged 0-14 years using current population (World Bank, 2014) and burden estimates (WPCA, 2014). Specifically, paediatric palliative care provision was mentioned in the national cancer control plans of four countries (Morocco Ministère de la Santé and Association Lalla Salma de Lutte Contre le Cancer, 2010-2019;

Table 2. Inclusion of palliative care domains in control plans

\begin{tabular}{|c|c|c|c|c|c|c|}
\hline & \multicolumn{6}{|c|}{ Inclusion of palliative care in plan } \\
\hline Country $^{a}$ & General need & Guideline/framework & Upstream approach & Access to analgesia & Budget & Evaluation \\
\hline \multicolumn{7}{|c|}{ Low-income economies } \\
\hline $\begin{array}{l}\text { Malawi } \\
\text { Madagascar } \\
\text { Burkina Faso } \\
\text { Zimbabwe } \\
\text { Kenyab }\end{array}$ & 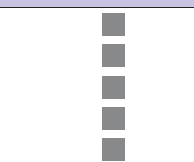 & $\square$ & 口 & $\square$ & $\square$ & 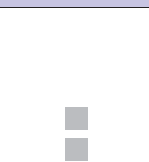 \\
\hline \multicolumn{7}{|c|}{ Lower-middle-income economies } \\
\hline $\begin{array}{l}\text { Côte d'Ivoire } \\
\text { Ghana } \\
\text { Moroccob }^{\text {b }}\end{array}$ & & $\square$ & $\square$ & $\square$ & $\square$ & 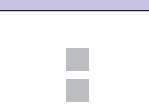 \\
\hline \multicolumn{7}{|c|}{ Upper-middle-income economies } \\
\hline $\begin{array}{l}\text { Algeria } \\
\text { South Africab } \\
\text { Mauritius }\end{array}$ & $\square$ & $\square$ & $\square$ & $\square$ & $\square$ & 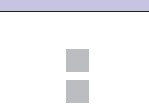 \\
\hline Continental & n & & (1) & a & & \\
\hline $\begin{array}{l}{ }^{{ }^{a} \text { Countries listec }} \\
22 \text { November } 2 \\
{ }^{b_{C}} \text { Countries spec }\end{array}$ & $\begin{array}{l}\text { der of increasing Gro } \\
\text { paediatric palliative }\end{array}$ & National Income per capita per & World Bank Atlas Method: htt & //data.worldbank.org/data-cat & rld-developn & :ators (last acces \\
\hline
\end{tabular}


Republic of Kenya Ministry of Public Health and Sanitation and Ministry of Medical Services, 2011-2016; South Africa Ministry of Health, 2013-2017; Zimbabwe Ministry of Health and Child Welfare, 2013-2017), representing 70318 children, or $11 \%$ of the expected continental burden (WPCA, 2014). Inclusion of palliative care need is provided as Table 2, with several plans emphasising palliative care including its upstream provision, and not only for patients at the end of life. Analgesic access was a dominant focus among most plans describing palliative care needs (Ministère de la Santé Publique République du Madagascar, 2010; Republic of Mauritius Ministry of Health and Quality of Life, 2010-2014; Morocco Ministère de la Santé and Association Lalla Salma de Lutte Contre le Cancer, 2010-2019; Ghana Ministry of Health, 2011; Republic of Kenya Ministry of Public Health and Sanitation and Ministry of Medical Services, 2011-2016; Burkina Faso Ministère de la Santé, 2013; African Organisation for Research and Training in Cancer (AORTIC), 2013-2017; South Africa Ministry of Health, 2013-2017; Zimbabwe Ministry of Health and Child Welfare, 2013-2017). Specific reference to national paediatric-specific palliative resources included mention of a training curriculum in Zimbabwe (Zimbabwe Ministry of Health and Child Welfare, 2013-2017) and a guideline for health care personnel in paediatric palliative care in South Africa (South Africa Ministry of Health, 2013-2017). In addition to paediatric-specific training, the Moroccan plan recognised the need for paediatric palliative facilities (Morocco Ministère de la Santé and Association Lalla Salma de Lutte Contre le Cancer, 2010-2019). The Kenyan plan mentioned need for palliative social services specific for children as a vulnerable group at the end of life (Republic of Kenya Ministry of Public Health and Sanitation and Ministry of Medical Services, 2011-2016). Resources for population-level palliative care were itemised in four budgets (Republic of Mauritius Ministry of Health and Quality of Life, 2010-2014; Morocco Ministère de la Santé and Association Lalla Salma de Lutte Contre le Cancer, 2010-2019; Ghana Ministry of Health, 2011; Burkina Faso Ministère de la Santé, 2013). No plan budget itemised paediatric-specific palliative care.

Paediatric cancer and paediatric palliative training. Three plans depicted the importance of general health workers receiving training in paediatric cancer management (Republic of Mauritius Ministry of Health and Quality of Life, 2010-2014; Ghana Ministry of Health, 2011; Burkina Faso Ministère de la Santé, 2013) with specific chemotherapy training for general paediatricians stated in an additional plan (Morocco Ministère de la Santé and Association Lalla Salma de Lutte Contre le Cancer, 2010-2019). One plan described development of postgraduate medical rotations in paediatric oncology (Zimbabwe Ministry of Health and Child Welfare, 2013-2017) and another planned to create a cadre of paediatric leukaemia scientists (African Organisation for Research and Training in Cancer (AORTIC), 2013-2017). Childhood cancer training specific for nurses was mentioned in another plan (Zimbabwe Ministry of Health and Child Welfare, 2013-2017). Palliative care training for all ages was prioritised in the continental plan (African Organisation for Research and Training in Cancer (AORTIC), 2013-2017) and seven national plans (Ministère de la Santé Publique République du Madagascar, 2010; Republic of Mauritius Ministry of Health and Quality of Life, 2010-2014; Morocco Ministère de la Santé and Association Lalla Salma de Lutte Contre le Cancer, 2010-2019; Ghana Ministry of Health, 2011; Republic of Kenya Ministry of Public Health and Sanitation and Ministry of Medical Services, 2011-2016; South Africa Ministry of Health, 2013-2017; Zimbabwe Ministry of Health and Child Welfare, 2013-2017). Exampled approaches to palliative care training included a national curriculum (Zimbabwe Ministry of Health and Child Welfare, 2013-2017), nursing and medical school training with provision of educational materials (Republic of Mauritius Ministry of Health and Quality of Life, 2010-2014), community worker training (Ministère de la Santé Publique République du Madagascar, 2010; Morocco Ministère de la Santé and Association Lalla Salma de Lutte Contre le Cancer, 2010-2019; Republic of Kenya Ministry of Public Health and Sanitation and Ministry of Medical Services, 2011-2016; South Africa Ministry of Health, 2013-2017), staff workshops (Republic of Mauritius Ministry of Health and Quality of Life, 2010-2014; Ghana Ministry of Health, 2011), and formal fellowship training (Ghana Ministry of Health, 2011). Two plans depicted paediatric-specific palliative care training (Morocco Ministère de la Santé and Association Lalla Salma de Lutte Contre le Cancer, 2010-2019; Zimbabwe Ministry of Health and Child Welfare, 2013-2017).

Paediatric cancer and paediatric palliative research. All nine of the cancer-specific control plans mentioned cancer research as an explicit priority (Ministère de la Santé Publique République du Madagascar, 2010; Republic of Mauritius Ministry of Health and Quality of Life, 2010-2014; Morocco Ministère de la Santé and Association Lalla Salma de Lutte Contre le Cancer, 2010-2019; Algérie Département de la Santé, 2010-2019; Ghana Ministry of Health, 2011; Republic of Kenya Ministry of Public Health and Sanitation and Ministry of Medical Services, 2011-2016; Burkina Faso Ministère de la Santé, 2013; African Organisation for Research and Training in Cancer (AORTIC), 2013-2017; Zimbabwe Ministry of Health and Child Welfare, 2013-2017).

None of the NCD plans mentioned cancer research as a priority beyond general NCD research. Two plans depicted inclusion of paediatric-focussed research: a call for research in national epidemiology of clustering for paediatric cancers (Republic of Mauritius Ministry of Health and Quality of Life, 2010-2014) and in childhood leukaemia, lymphoma, and Kaposi sarcoma (African Organisation for Research and Training in Cancer (AORTIC), 2013-2017). Further research into the ethics of clinical investigation was nicely depicted in the Senegalese plan (République du Sénégal Ministère de la Santé et de la Prévention, 2009).

Monitoring and evaluation. Measurable paediatric cancer outcomes were outlined in three national plans (Republic of Mauritius Ministry of Health and Quality of Life, 2010-2014; Ghana Ministry of Health, 2011; Zimbabwe Ministry of Health and Child Welfare, 2013-2017). Zimbabwe committed to decrease the percent of late diagnosis in specified childhood cancers by $30 \%$ by 2017 (Zimbabwe Ministry of Health and Child Welfare, 2013-2017). Mauritius committed to a year by which the paediatric cancer ward would be functional (Republic of Mauritius Ministry of Health and Quality of Life, 2010-2014). Morocco committed to cure for at least $50 \%$ of paediatric cancer patients (Morocco Ministère de la Santé and Association Lalla Salma de Lutte Contre le Cancer, 2010-2019). Measurable palliative outcomes were stated in six national plans (Republic of Mauritius Ministry of Health and Quality of Life, 2010-2014; Morocco Ministère de la Santé and Association Lalla Salma de Lutte Contre le Cancer, 2010-2019; Ghana Ministry of Health, 2011; Republic of Kenya Ministry of Public Health and Sanitation and Ministry of Medical Services, 2011-2016; South Africa Ministry of Health, 2013-2017; Zimbabwe Ministry of Health and Child Welfare, 2013-2017), although no plan specified paediatric palliative care evaluation metrics. Non-exclusive examples of specific, measurable, relevant, and timely palliative care evaluations included: Ghana's objective to provide palliative care to $25 \%$ of all eligible patients by 2020 (Ghana Ministry of Health, 2011); Kenya's five-year palliative metric plan including number of providers trained, number of policy documents, and reports on services rendered (Republic of Kenya Ministry of Public Health and Sanitation and Ministry of Medical Services, 2011-2016); and Mauritius' strategic timeline for extending palliative training and home care services to measurable 
geographic regions (Republic of Mauritius Ministry of Health and Quality of Life, 2010-2014).

Registries. The AORTIC Plan depicted a continental priority to 'improve the validity of cancer registration for childhood cancers' (African Organisation for Research and Training in Cancer (AORTIC), 2013-2017). Population-based cancer registries were mentioned as being in varying levels of function, with initiated national registry efforts mentioned in South Africa (South Africa Ministry of Health, 2013-2017), Zimbabwe (Zimbabwe Ministry of Health and Child Welfare, 2013-2017), Ghana (Ghana Ministry of Health, 2011), Mauritius (Republic of Mauritius Ministry of Health and Quality of Life, 2010-2014), Côte d'Ivoire (Ministère de la Santé et de la Lutte contre le SIDA République de Côte d'Ivoire, 2011-2014), and Mali (Ministère de la Santé République du Mali, 2013); regional efforts in Morocco (Morocco Ministère de la Santé and Association Lalla Salma de Lutte Contre le Cancer, 2010-2019) and Algeria (Algérie Département de la Santé, 2010-2019); city data in Kenya (Republic of Kenya Ministry of Public Health and Sanitation and Ministry of Medical Services, 2011-2016); and extrapolated hospital-based statistics in Benin (République de Bénin Ministère de la Santé, 2014-2018), Togo (République Togolaise Ministère de la Santé, 2012), Burkina Faso (Burkina Faso Ministère de la Santé, 2013), and Madagascar (Ministère de la Santé Publique République du Madagascar, 2010). Seven plans provided an epidemiologic representation of childhood cancers in the country (Ministère de la Santé Publique République du Madagascar, 2010; Republic of Mauritius Ministry of Health and Quality of Life, 2010-2014; Ghana Ministry of Health, 2011; Ministère de la Santé et de la Lutte contre le SIDA République de Côte d'Ivoire, 2011-2014; Burkina Faso Ministère de la Santé, 2013; Zimbabwe Ministry of Health and Child Welfare, 2013-2017; République de Bénin Ministère de la Santé, 2014-2018). While the historic lack of population-based registries complicates consistent national estimates of childhood cancer, the continental plan depicted incidence of childhood cancer per million children under 15 years of age as 71.2 in Nigeria, 100 in Malawi, 183.5 in Uganda, 111.2 in Zimbabwe, and 77.4 in Mali (African Organisation for Research and Training in Cancer (AORTIC), 2013-2017). Data on the epidemiologic impact of national cancer control plans are not yet stated in existing plans, although plans' stated goal of data monitoring over time should facilitate this cancer intelligence reporting in future plans.

All plans mentioned the goal of improved accuracy or function of population health registries with some mentioning budget (Burkina Faso Ministère de la Santé, 2013) and technology needs (Republic of the Sudan Federal Ministry of Health, 2003-2027) for implementation. Plans recognised the need for closer outcome tracking, including as a functioning death certification/notification process linked to cancer registries (Morocco Ministère de la Santé and Association Lalla Salma de Lutte Contre le Cancer, 2010-2019). Goals for palliative data gathering included monitoring drug availability and utilisation (Republic of Mauritius Ministry of Health and Quality of Life, 2010-2014; South Africa Ministry of Health, 2013-2017), care costs (Republic of Mauritius Ministry of Health and Quality of Life, 2010-2014; Burkina Faso Ministère de la Santé, 2013), and service needs compared with service access (Ghana Ministry of Health, 2011).

Equity measures. In addition to the holistic promotion of equity in health services, funding and implementation as outlined above, several plans outlined specific measures to promote equity in practice.

The goal for trained personnel inclusive of both genders was highlighted in the Morocco plan. The Zimbabwe plan suggested research priorities to include cancer screening in marginalised female populations. The Malawi plan articulated a performance indicator of population satisfaction with health services by gender.

The NCD plan for Botswana described improved health literacy as a strategic objective with an actionable plan to establish and strengthen community resource centres and health libraries through the development of age-, gender-, and culturally-sensitive health learning materials (Ministry of Health Government of Botswana, 2010). Guided by the Health Literacy/Promotion Taskforce, the Zimbabwean program included a measurable health literacy outcome: to increase the proportion of Zimbabweans who are cancer literate to $80 \%$ by 2017 (Zimbabwe Ministry of Health and Child Welfare, 2013-2017).

Universal health insurance was listed as an intention in 12 plans (Republic of the Sudan Federal Ministry of Health, 2003-2027; République du Sénégal Ministère de la Santé et de la Prévention, 2009; Ministry of Health Government of Botswana, 2010; République Gabonaise Ministère de la Santé des Affaires Sociales de la Solidarité et de la Famille, 2010; Republic of Mauritius Ministry of Health and Quality of Life, 2010-2014; Morocco Ministère de la Santé and Association Lalla Salma de Lutte Contre le Cancer, 2010-2019; Ghana Ministry of Health, 2011; Republic of Kenya Ministry of Public Health and Sanitation and Ministry of Medical Services, 2011-2016; Malawi Ministry of Health, 2011-2016; Ministère de la Santé République du Mali, 2013; African Organisation for Research and Training in Cancer (AORTIC), 2013-2017; South Africa Ministry of Health, 2013-2017) with existing free public health services in Mauritius (Republic of Mauritius Ministry of Health and Quality of Life, 2010-2014) and two other plans specifying governmental and nongovernmental efforts to provide financial support for children with cancer (Ghana Ministry of Health, 2011; Zimbabwe Ministry of Health and Child Welfare, 2013-2017). Kenya included the accountability of a 5-year indicator as the proportion of insurance firms covering cancer services (Republic of Kenya Ministry of Public Health and Sanitation and Ministry of Medical Services, 2011-2016). Sudan stated a measurable commitment of balancing budget allocation between rural and urban areas with a plan to increase telecommunication in remote areas (Republic of the Sudan Federal Ministry of Health, 2003-2027).

Treatment abandonment. Treatment abandonment, defined as the failure to start or complete medically indicated curative therapy, represents a key patient outcome in resource-limited settings (Mostert et al, 2011). The burden of treatment abandonment was mentioned in four plans (Ghana Ministry of Health, 2011; Burkina Faso Ministère de la Santé, 2013; Zimbabwe Ministry of Health and Child Welfare, 2013-2017; République de Bénin Ministère de la Santé, 2014-2018), with one plan depicting abandonment as a barrier to cure for 'most patients' (Burkina Faso Ministère de la Santé, 2013). General challenges in monitoring and follow-up of cancer patients throughout the care and posttherapy course were also articulated (Morocco Ministère de la Santé and Association Lalla Salma de Lutte Contre le Cancer, 2010-2019), with the Moroccan plan specifying strategies including documentation and provider coordination, as well as related indicators to monitor treatment completion and follow-up. Transport was recognised as a pragmatic need in seven plans (Republic of the Sudan Federal Ministry of Health, 2003-2027; République du Sénégal Ministère de la Santé et de la Prévention, 2009; Republic of Mauritius Ministry of Health and Quality of Life, 2010-2014; Malawi Ministry of Health, 2011-2016; South Africa Ministry of Health, 2013-2017; Zimbabwe Ministry of Health and Child Welfare, 2013-2017; Morocco Ministère de la Santé and Association Lalla Salma de Lutte Contre le Cancer, 2010-2019) with explicit link to abandonment risk for children with cancer in one plan (Zimbabwe Ministry of Health and Child Welfare, 2013-2017), while another mentioned regional chemotherapy 
administration to avoid travel barriers (Republic of Mauritius Ministry of Health and Quality of Life, 2010-2014). The Moroccan plan provided an exemplary commitment to provision of secure, free transportation between oncology centres and the patient's home (Morocco Ministère de la Santé and Association Lalla Salma de Lutte Contre le Cancer, 2010-2019). The Ghana plan specifically linked prioritisation of housing to treatment completion outcomes: 'hostels for children and carers to stay for duration of treatment are required to reduce abandonment of treatment' (Ghana Ministry of Health, 2011). The Malawi plan recognised the need for households to have toilets and safe water (Malawi Ministry of Health, 2011-2016). Two plans remarked on employment protection (Morocco Ministère de la Santé and Association Lalla Salma de Lutte Contre le Cancer, 2010-2019; Zimbabwe Ministry of Health and Child Welfare, 2013-2017), with the Zimbabwean plan mentioning the task to 'educate patients, family members, and the public on existing laws that protect their legal rights through Ministry of Labour' and measurable outcome of the number of protected jobs (Zimbabwe Ministry of Health and Child Welfare, 2013-2017).

Treatment adherence. Adherence counselling and engagement of community-based support including community health workers were noted as part of comprehensive NCD care (South Africa Ministry of Health, 2013-2017) with crosslink lessons from HIV adherence (Ministry of Health Government of Botswana, 2010) and TB decentralised approaches (République du Sénégal Ministère de la Santé et de la Prévention, 2009), reminding oncology teams that opportunities to improve adherence span NCD diagnoses.

\section{DISCUSSION}

This review of contemporary CCPs in Africa highlighted notable examples of paediatric cancer control and palliative care needs as well as sample commitments made on a national and continental level. Prominently, the majority of publically available plans did not yet specify inclusion of paediatric elements (in 11 of 19 plans), nor paediatric-specific palliative care (in 15 of 19 plans), although a number exemplified recognition of the unique needs of children with cancer. While recognising distinct variability in population size, geography, language, culture, ethnic groups, sociopolitical stability, strength of economies, and health systems among a multitude of features particular to (and heterogeneous even within) each country, our analysis also allowed recognition of shared features. Furthermore, our examples supported how commitments to paediatric cancer and palliative care are not necessarily limited by national wealth or progress to date, as exemplary commitments spanned across all income-level economies (World Bank, 2014), previously reported levels of child-friendly governance (Bequele, 2010), as well as levels of paediatric palliative care provision (Knapp et al, 2011).

Review of existing cancer control plans has the potential to inform development of future iterations of CCP framing and development. Although it was beyond the scope of this project to undertake analyses of plan implementation within broader health policies and on-the-ground practices, review of scripted CCPs support the need to further advocate for paediatric- and palliativesensitive elements within national cancer control strategies. Specific areas for targeted intervention include mandating childhood cancer reporting and registration, accurate and early diagnosis, and coverage for childhood cancer treatment. In the current setting including late diagnosis and scarce diagnostic and therapeutic resources, the plans revealed notable opportunities for palliative care partnerships and collaborations across diagnoses. Explicit strategies and funding for paediatric and palliative services in national cancer plans may help guide prioritised health delivery implementation. Based on review of these national cancer control plans, priority areas for policy, resources, and action include: diligent monitoring of childhood cancer cases and outcomes in the context of existing health service delivery; tangible commitment and multisector stakeholder engagement to minimise threats to outcomes such as treatment abandonment and inaccessibility of essential staff and supplies; and longitudinal evaluation of control plan interventions to optimise equity, integration, and responsiveness of health system elements. Advocacy and funding accountability remain essential to shift plans from paper to improved population outcomes.

We focussed this review on paediatric populations, noting during this process that the context of adolescence remained inconsistently described. The Mauritius plan noted that adolescents with cancer were treated with adults. While several plans recognised the unique phase of adolescence, including adolescents' developmental vulnerability (Ministry of Health Government of Botswana, 2010; Malawi Ministry of Health, 2011-2016), stressors (République du Sénégal Ministère de la Santé et de la Prévention, 2009), and potential benefit from adolescent-specific and youth- and adult-partnered services (Ministry of Health Government of Botswana, 2010), needs for adolescent-specific cancer care and transition between paediatric and adult services appear to be an area meriting further focus (Institute of Medicine National Cancer Policy Forum, 2013).

Including current plans, whether as an NCD or cancer-specific plan format, enabled the study team to think outside of subspecialty silos. Plans that incorporated prompt diagnosis and treatment of infectious diseases modelled cross-over between subspecialties: Burkitt lymphoma is commonly associated with holoendemic malaria and Epstein-Barr virus, whereas Kaposi's sarcoma is associated with coinfection with HIV and high titres of human herpes virus- 8 (African Organisation for Research and Training in Cancer (AORTIC), 2013-2017). Similarly, safe blood supply is a concern across HIV and oncological teams as depicted in Botswana's NCD plan (Ministry of Health Government of Botswana, 2010). Interventions that improve treatment adherence and treatment completion have the potential to span NCDs. Cancer treatment abandonment rates in Africa are as high as $26 \%$ in Mali (Togo et al, 2014), 54\% in western Kenya (Njuguna et al, 2014), 46\% in Zambia (Slone et al, 2014), thus plans that prioritise treatment completion have arguably the greatest potential for impact on survival rates in childhood cancer.

This evaluation model provides a start to assessing the progress made toward paediatric cancer and palliative care, and the future data collection and resource needs for sustainable care measures. Disseminating best practices from these written plans has the potential to support and complement work across NCDs. Longterm evaluation strategies benefit from measurable and timely objectives, both for advocacy and for accountability. Attentiveness to paediatric cancer and palliative care outcome evaluation is now essential to track progress toward achieving objectives and goals.

\section{CONCLUSION}

Commitment to cancer control must encompass the needs of children and palliative care. This analysis for paediatric- and palliative carespecific elements can inform the development of future plans within Africa and low- and middle-income countries elsewhere, particularly the next step of implementation and evaluation of impact.

\section{ACKNOWLEDGEMENTS}

The research team wishes to thank Dr Fidel Rubagumya (Rwanda), Dr Angèle Pondy (Cameroon), and Professor Barsaoui Sihem (Tunisia). 


\section{CONFLICT OF INTEREST}

The authors declare no conflict of interest.

\section{REFERENCES}

African Organisation for Research and Training in Cancer (AORTIC) (2013- 2017) Cancer Plan for the African Continent 2013-2017. Available at http://www.iccp-portal.org/sites/default/files/plans/ AORTIC_CANCER_PLAN\%20AFRICA.pdf.

Algérie Département de la Santé (2010-2019) Engagement solennel au plus haut niveau de l'état qui fait du cancer une priorité nationale 2010-2019. Available at http://www.thewhpca.org/resources/item/national-cancerprevention-and-control-plan-2010-2019.

American Cancer Society (2000) National Action Plan For Childhood Cancer Report of the National Summit Meetings on Childhood Cancer. Available at http://www.cancer.org/acs/groups/content/@nho/documents/ document/childhoodcanceractionplanpdf.pdf.

Amery JM, Rose CJ, Holmes J, Nguyen J, Byarugaba C (2009) The beginnings of children's palliative care in Africa: evaluation of a children's palliative care service in Africa. J Palliat Med 12(11): 1015-1021.

Atun R, Ogawa T, Martin-Moreno JM (2009) Analysis of national cancer control programmes in Europe. Imperial College London: London.

Bequele A (2010) Monitoring the commitment and child-friendliness of governments: a new approach from Africa. Child abuse \& neglect 34(1): $34-44$.

Burkina Faso Ministère de la Santé (2013) Plan stratégique de lutte contre le cancer 2013-2017. Available at http://www.iccp-portal.org/sites/default/ files/plans/Burkina\%20Faso_Plan\%20strat\%C3\%A9gique\%20de\%20lutte\% 20contre\%20le\%20cancer\%202013-2017.pdf.

Farmer P, Frenk J, Knaul FM, Shulman LN, Alleyne G, Armstrong L, Atun R, Blayney D, Chen L, Feachem R, Gospodarowicz M, Gralow J, Gupta S, Langer A, Lob-Levyt J, Neal C, Mbewu A, Mired D, Piot P, Reddy KS, Sachs JD, Sarhan M, Seffrin JR (2010) Expansion of cancer care and control in countries of low and middle income: a call to action. Lancet 376(9747): 1186-1193.

Ferlay J, Soerjomataram I, Ervik M, Dikshit R, Eser S, Mathers C, Rebelo M, Parkin DM, Forman D, Bray F (2013) GLOBOCAN 2012 v1.0, Cancer Incidence and Mortality Worldwide: IARC CancerBase No. 11. International Agency for Research on Cancer. Available at http:// globocan.iarc.fr (accessed 1 November 2014).

Ghana Ministry of Health (2011) National Strategy for Cancer Control in Ghana 2012-2016. Available at http://www.iccp-portal.org/sites/default/ files/plans/Cancer\%20Plan\%20Ghana\%202012-2016.pdf.

Given LS, Hohman K, Graaf L, Rochester P, Belle-Isle L (2010) From planning to implementation to outcomes: comprehensive cancer control implementation building blocks. Cancer causes \& control 21(12): 1987-1994.

Harding R, Selman L, Powell RA, Namisango E, Downing J, Merriman A, Ali Z, Gikaara N, Gwyther L, Higginson I (2013) Research into palliative care in sub-Saharan Africa. Lancet Oncol 14(4): e183-e188.

Harford JB, Edwards BK, Nandakumar A, Ndom P, Capocaccia R, Coleman MP. Group I-SA (2009) Cancer control-planning and monitoring population-based systems. Tumori 95(5): 568-578.

Harif M, Barsaoui S, Benchekroun S, Bouhas R, Doumbe P, Khattab M, Ladjaj Y, Moreira C, Msefer-Alaoui F, Patte C, Rakotonirina G, Raphael M, Raquin MA, Lemerle J (2008) Treatment of B-cell lymphoma with LMB modified protocols in Africa-report of the French-African Pediatric Oncology Group (GFAOP). Pediatr Blood Cancer 50(6): 1138-1142.

Harif M, Traore F, Hessissen L, Moreira C, Atteby JJ (2013) Challenges for paediatric oncology in Africa. Lancet Oncol 14(4): 279-281.

Howard SC, Metzger ML, Wilimas JA, Quintana Y, Pui CH, Robison LL, Ribeiro RC (2008) Childhood cancer epidemiology in low-income countries. Cancer 112(3): 461-472.

Institute of Medicine National Cancer Policy Forum (2013) Identifying and Addressing the Needs of Adolescents and Young Adults with Cancer. Institute of Medicine: Washington, DC, USA. Available at http://iom.edu/ Reports/2013/Identifying-and-Addressing-the-Needs-of-Adolescents-andYoung-Adults-with-Cancer.aspx.

Israels T, Borgstein E, Pidini D, Chagaluka G, de Kraker J, Kamiza S, Molyneux EM (2012) Management of children with a Wilms tumor in Malawi, sub-Saharan Africa. J Pediatr Hematol Oncol 34(8): 606-610.

Knapp C, Woodworth L, Wright M, Downing J, Drake R, Fowler-Kerry S, Hain R, Marston J (2011) Pediatric palliative care provision around the world: a systematic review. Pediatr Blood Cancer 57(3): 361-368.

Kruger M, Hendricks M, Davidson A, Stefan CD, van Eyssen AL, Uys R, van Zyl A, Hesseling P (2014) Childhood cancer in Africa. Pediatr Blood Cancer 61(4): 587-592.

Lynch T, Connor S, Clark D (2013) Mapping levels of palliative care development: a global update. J Pain Symptom Manage 45(6): 1094-1106.

Magrath I, Steliarova-Foucher E, Epelman S, Ribeiro RC, Harif M, Li CK, Kebudi R, Macfarlane SD, Howard SC (2013) Paediatric cancer in lowincome and middle-income countries. Lancet Oncol 14(3): e104-e116.

Malawi Ministry of Health (2011-2016) Malawi Health Sector Strategic Plan 2011-2016. Available at http://malawipublichealth.org/wp-content/ uploads/2014/03/Malawi-HSSP-Summary.pdf.

Ministère de la Santé et de la Lutte contre le SIDA République de Côte d'Ivoire (2011-2014) Politique nationale de prévention et de prise en charge des maladies chroniques non transmissibles en Côte d'Ivoire 2011-2014. Available at http://www.iccp-portal.org/sites/default/files/plans/ MNT\%20COTE\%20IVOIRE\%202011\%202014.pdf.

Ministère de la Santé Publique République du Madagascar (2010) Politique nationale de lutte contre le cancer à Madagascar 2010. Available at http://www.iccp-portal.org/sites/default/files/plans/Madasgascar\%20\%20Politique\%20Nationale\%20cancer\%202010.pdf.

Ministère de la Santé Publique République du Mali (2013) Politique nationale de lutte contre les maladies non transmissibles 2012-2016. Available at http://www.iccp-portal.org/sites/default/files/plans/Mali-Politique\% 20nationale $\% 20 \mathrm{de} \% 20$ utte $\% 20$ contre $\% 20$ les $\% 20$ maladies \%20non\%20transmissibles\%202013.pdf.

Ministry of Health Government of Botswana (2010) Integrated Health Service Plan: A Strategy for Changing the Health Sector for Healthy Botswana 2010-2020. Available at http://www.moh.gov.bw/Publications/policies/ Botswana\%20IHSP\%20Final\%20HLSP.pdf.

Momin B, Richardson L (2012) An analysis of content in comprehensive cancer control plans that address chronic hepatitis $\mathrm{B}$ and $\mathrm{C}$ virus infections as major risk factors for liver cancer. J Community Health 37(4): 912-916.

Morocco Ministère de la Santé and Association Lalla Salma de Lutte Contre le Cancer (2010-2019) National Cancer Prevention and Control Plan 2010-2019. Available at http://www.iccp-portal.org/sites/default/files/plans/ PNPCC_-_Axes_strategiques_et_mesures_2010-2019.pdf.

Mostert S, Arora RS, Arreola M, Bagai P, Friedrich P, Gupta S, Kaur G, Koodiyedath B, Kulkarni K, Lam CG, Luna-Fineman S, Pizer B, Rivas S, Rossell N, Sitaresmi MN, Tsimicalis A, Weaver M, Ribeiro RC (2011) Abandonment of treatment for childhood cancer: position statement of a SIOP PODC Working Group. Lancet Oncol 12(8): 719-720.

National Consensus Project for Quality Palliative Care (2013) Clinical Practice Guidelines for Quality Palliative Care. National Consensus Project for Quality Palliative Care: Pittsburgh.

Njuguna F, Mostert S, Slot A, Langat S, Skiles J, Sitaresmi MN, van de Ven PM, Musimbi J, Muliro H, Vreeman RC, Kaspers GJ (2014) Abandonment of childhood cancer treatment in Western Kenya. Arch Dis Child 99(7): 609-614.

Parkin DM (2006) The evolution of the population-based cancer registry. Nature reviews Cancer 6(8): 603-612.

Parkin DM, Stiller CA, Draper GJ, Bieber CA (1988) The international incidence of childhood cancer. Int J Cancer 42(4): 511-520.

Republic of Kenya Ministry of Public Health and Sanitation and Ministry of Medical Services (2011-2016) National Cancer Control Strategy 2011-2016. Available at http://www.iccp-portal.org/sites/default/files/ plans/Kenya-National-Cancer-Control-strategy.pdf.

Republic of Mauritius Ministry of Health and Quality of Life (2010-2014) National Cancer Control Programme Action Plan 2010-2014. Available at http://www.iccp-portal.org/sites/default/files/plans/cancer-ap.pdf.

Republic of the Sudan Federal Ministry of Health (2003-2027) Twenty-Five Years Strategic Plan for the Health Sector 2003-2027. Available at www.fmoh.gov.sd/English/St_Plan/doc/strategic.pdf.

République de Bénin Ministère de la Santé (2014-2018) Plan stratégique integré de lutte contre les maladies non transmissibles 2014-2018. Available at http://www.iccp-portal.org/sites/default/files/plans/ plan_strategique_integre_lutte_contre_maladies_non_transmissibles_ VF_Imprimerie.pdf. 
République du Sénégal Ministère de la Santé et de la Prévention (2009) Plan National de Développement Sanitaire 2009-2018. Available at http:// www.nationalplanningcycles.org/sites/default/files/country_docs/Senegal/ senegal_plan_national_de_developpment_sanitaire_2009-2018.pdf.

République Gabonaise Ministère de la Santé des Affaires Sociales de la Solidarité et de la Famille (2010) Plan National de Développement Sanitaire 2011-2015. Available at http://www.nationalplanningcycles.org/ sites/default/files/country_docs/Gabon/pnds_2011_2015.pdf.

République Togolaise Ministère de la Santé (2012) Politique et plan stratégique integré de lutte contre les maladies non transmissibles 2012-2015. Available at http://www.iccp-portal.org/sites/default/files/ plans/Version_Finale_PSI_MNT_2012_-2015.pdf.

Ribeiro RC, Steliarova-Foucher E, Magrath I, Lemerle J, Eden T, Forget C, Mortara I, Tabah-Fisch I, Divino JJ, Miklavec T, Howard SC, Cavalli F (2008) Baseline status of paediatric oncology care in ten low-income or mid-income countries receiving My Child Matters support: a descriptive study. Lancet Oncol 9(8): 721-729.

Sitas F, Parkin DM, Chirenje M, Stein L, Abratt R, Wabinga H (2008) Part II: Cancer in Indigenous Africans-causes and control. Lancet Oncol 9(8): 786-795.

Slone JS, Chunda-Liyoka C, Perez M, Mutalima N, Newton R, Chintu C, Kankasa C, Chipeta J, Heimburger DC, Vermund SH, Friedman DL (2014) Pediatric malignancies, treatment outcomes and abandonment of pediatric cancer treatment in Zambia. PLoS One 9(2): e89102.

South Africa Ministry of Health (2013-2017) Strategic Plan for the Prevention and Control of Non-Communicable Diseases 2013-2017. Available at http://www.iccp-portal.org/sites/default/files/plans/NCDs-STRAT-PLANCONTENT-8-april-proof.pdf.

Stefan DC, Elzawawy AM, Khaled HM, Ntaganda F, Asiimwe A, Addai BW, Wiafe S, Adewole IF (2013) Developing cancer control plans in Africa: examples from five countries. Lancet Oncol 14(4): e189-e195.

Sullivan R (2012) Putting public health back into the global cancer agenda. Ann Oncol 23(12): 2995-2996.

Sullivan R, Kowalczyk JR, Agarwal B, Ladenstein R, Fitzgerald E, Barr R, Steliarova-Foucher E, Magrath I, Howard SC, Kruger M, Valsecchi MG, Biondi A, Grundy P, Smith MA, Adamson P, Vassal G, Pritchard-Jones K (2013) New policies to address the global burden of childhood cancers. Lancet Oncol 14(3): e125-e135.

Togo B, Traore F, Togo AP, Togo P, Diakite AA, Traore B, Toure A, Coulibaly Y, Traore CB, Fenneteau O, Sylla F, Dumke H, Diallo M, Diallo G, Sidibe T (2014) [Epidemiology and prognosis of childhood cancers at Gabriel-Touré Teaching Hospital (Bamako, Mali)]. Médecine et Santé Tropicales 24(1): 68-72.

UICC (2008) World Cancer Declaration. Union for International Cancer Control: Geneva, Switzerland. Available at http://www.uicc.org/world-cancer-declaration.
UICC (2012) Supporting National Cancer Control Planning: A Toolkit for Civil Society Organisations (CSOS). Union for International Cancer Control: Geneva, Switzerland. Available at http://www.uicc.org/sites/main/files/ private/eNCCPTOOLK_FA_0_0.pdf.

UICC (2014) International Cancer Control Partnership (ICCP) Portal. Available at http://www.iccp-portal.org/cancer-plans (accessed 1 November 2014).

UNICEF and ICPCN (2013) Assessment of the Need for Palliative Care for Children Three Country Report: South Africa, Kenya, and Zimbabwe. United Nations International Children's Fund and International Children's Palliative Care Network: New York, NY, USA. Available at http://www.icpcn.org/wp-content/uploads/2013/11/Assessment-of-theNeed-for-Palliative-Care-for-Children.-Three-Country-Report-SouthAfrica-Kenya-and-Zimbabawe.pdf.

UNICEF (2014) Generation 2030/AFRICA. Available at http://www.unicef. org/publications/index_74751.html (accessed 1 November 2014).

Vento S (2013) Cancer control in Africa: which priorities? Lancet Oncol 14(4): $277-279$.

WHO (2002) National Cancer Control Programmes: Policies and Managerial Guidelines. World Health Organization: Geneva, Switzerland, Available at http://www.who.int/cancer/publications/nccp2002/en/.

WHO (2006) Cancer Control: Knowledge into Action: Who Guide for Effective Programmes. World Health Organization: Geneva, Switzerland. Available at http://www.who.int/cancer/modules/en/.

WHO (2009) Closing the Gap in a Generation: Health Equity Through Action on the Social Determinants of Health. Report of the Commission on Social Determinants and Health. World Health Organization: Geneva, Switzerland. Available at http://www.who.int/tb/challenges/mdr/ ethics_closingthegap/en/.

WHO (2010) National cancer control programmes. Available at http:// www.who.int/cancer/nccp/en/ (accessed 1 November 2014).

World Bank (2014) The World Bank: Data. Available at http://data. worldbank.org (accessed 1 November 2014).

WPCA (2014) Global Atlas of Palliative Care at End of Life. Worldwide Palliative Care Alliance and World Health Organization: London, UK. Available at http://www.who.int/cancer/publications/palliative-care-atlas/en/.

Zimbabwe Ministry of Health and Child Welfare (2013-2017) The National Cancer Prevention and Control Strategy for Zimbabwe 2013-2017. Available at http://www.iccp-portal.org/sites/default/files/plans/ Zimbabwe\%20Cancer\%20Control\%20Strategy.pdf.

This work is published under the standard license to publish agreement. After 12 months the work will become freely available and the license terms will switch to a Creative Commons AttributionNonCommercial-Share Alike 4.0 Unported License

Supplementary Information accompanies this paper on British Journal of Cancer website (http://www.nature.com/bjc) 